\title{
Self Regulated Learning, Self-Esteem, Dukungan Sosial dan Flow Akademik
}

\section{Self Regulated Learning, Self-Esteem, Social Support and Academic Flow}

\author{
Raida Daulah Amira ${ }^{1}$, Abdul Muhid ${ }^{*}$ \\ ${ }^{1}$ Fakultas Psikologi dan Kesehatan, Universitas Islam Negeri Ampel Surabaya \\ *abdulmuhid1975@gmail.com
}

\begin{abstract}
Abstrak
Tujuan penelitian ini adalah untuk mengetahui hubungan antara self regulated learning, self-esteem, dukungan sosial dengan flow akademik pada siswa Program SKS dan Program Reguler. Penelitian ini merupakan jenis penelitian kuantitatif korelasional. Alat pengumpulan data dalam penelitian ini menggunakan skala seelf regulated learning, skala self esteem, skala dukungan sosial, dan skala flow akademik. Subjek dalam penelitian ini berjumlah 85 dari total populasi 890 siswa MAN 2 Kota Probolinggo melalui teknik menggunakan penelitian populasi dan quota sampling. Metode yang digunakan dalam penelitian ini adalah metode kuantitatif dengan teknik analisis berganda. Hasil penelitian menujukkan nilai $\mathrm{F}$ hitung $=38.874$ dengan signifikansi $0.000<0.05$, Hal ini menunjukkan bahwa hubungan self regulated learning, self-esteem, dan dukungan sosial secara bersama flow akademik pada siswa program sks dan program reguler, terdapat hubungan yang signifikan. Sehingga hipotesis yang diajukan diterima, artinya semakin tinggi self regulated learning, self-esteem, dukungan sosial yang dimiliki, maka akan semakin tinggi pula flow akademik yang dirasakan.
\end{abstract}

Kata kunci: Self regulated learning, Self-esteem, Dukungan Sosial, Flow Akademik

\begin{abstract}
The purpose of this study was to determine the relationship between self regulated learning, self-esteem, social support with academic flow in students in the credits programs and regular programs. This research is a type of correlational quantitative research. In this research use the scale of self regulated learning, self-esteem scale, social support scale, and academic flow scale. The research subject compensated 85 from a total population of 890 through the population research and quota sampling. The method used in this study is a quantitative method with multiple analysis technique. The result showed the calculated $F$ value $=38.874$ with a significance of $0.000<0.05$. This shows that the relationship of self regulated learning, self-esteem, social support together with academic flow among students in the credit program and reguler program, there is a significant relationship. So the proposed hypothesis is accepted, meaning that the self regulated learning, self-esteem, and social support they have, the higher the academic flow.
\end{abstract}

Keywords: Self regulated learning, Self-esteem, Social Support, Academic Flow

\section{Pendahuluan}

Keberhasilan suatu pendidikan dapat berhasil dengan berbagai faktor, salah satu faktor penyebabnya adalah proses pembelajaran. Proses pembelajaran adalah interaksi timbal balik antara guru dan siswa. Proses pembelajaran ini berlangsung secara edukatif sehingga tercapai tujuan pembelajaran (Rustaman, 2011). Tujuan belajar merupakan untuk mengembangkan suatu pengetahuan, keterampilan, dan sikap siswa untuk mencapai hasil belajar yang optimal (Daryanto, 2005). Terkadang padatnya jam belajar di sekolah yang panjang dan beban belajar siswa seringkali membuat mereka mengalami kelelahan fisik dan mental sehingga menyebabkan munculnya kejenuhan belajar (Syah, 
2012). Menurut Al-Qawiy (2004), kejenuhan belajar adalah tekan secara mendalam dan sudah berada di titik jenuh. Kejenuhan belajar merupakan kondisi mental individu saat merasa lelah dan bosan sehingga mengakibatkan timbulnya rasa tidak bersemangat, lesu saat proses pembelajaran (Thursan, 2000). Survei yang dilakukan Yazzie-Mintz dalam Furlong, Gilman, and Huebner (2009) menjelaskan bahwa kebosanan sudah menjadi karakter setiap sekolah, rata-rata siswa SMA 66\% mengalami kebosanan di sekolah dan $17 \%$ kebosanan di dalam kelas.

Masa remaja merupakan masa peralihan dari masa kanak-kanak menuju ke masa dewasa. Perubahan banyak terjadi pada masa ini, salah satunya ialah kesadaran mengenai diri sendiri, meyakini kemampuan yang dimilikinya, potensi diri, dan cita-cita yang ingin dicapai, maka mereka berusaha untuk menemukan jalan hidupnya dan mencari nilai-nilai kehidupan (Kartono, 1990). Dalam proses untuk tercapainya kesuksesan diri pada siswa diperlukan sebuah kenyamanan, fokus yang tinggi, dan konsentrasi dalam proses belajar untuk memperoleh hasil yang diinginkan. Ofianto menyebutkan bahwa setiap anak mendapat proses belajar sesuai dengan kondisi, kebutuhan, kemampuan, dan minat siswa untuk memperoleh hasil belajar yang maksimal (Ofianto, 2015).

Ketika seorang individu bisa fokus dan terhanyut pada aktivitas yang sedang dilakukan, sehingga seluruh perhatiannya tercurahkan pada aktivitas tersebut dinamakan flow (Prawitasari, 2011). Lee (2005) menyebutkan bahwa flow merupakan kondisi seseorang melibatkan perasaan positif, sehingga individu tersebut mampu mengendalikan dirinya untuk tetap fokus terhadap apa yang sedang dilakukannya. Siswa yang mengalami flow dapat mengikuti setiap proses pembelajaran dengan perasaan senang, nyaman, kosentrasi penuh dalam proses pembelajaran maka kondisi seperti itu disebut dengan flow akademik (Yuwanto et al. 2011). Menurut Shernoff et al. (2014) Shernoff flow akademik merupakan gairah dan minat mengerjakan tugas, merasa senang, individu sadar menurahkan seluruh kemampuannya dalam mengerjakan tugas.

Ciri-ciri seseorang mengalami flow akademik yakni merasa nyaman dan aktif dalam kegiatan belajar (Purwati \& Akmaliyah, 2016). Flow akademik memiliki tiga aspek yang membentuk yakni, pertama absorption (penyerapan) merupakan kemampuan individu untuk konsentrasi dalam melakukan aktivitas, kedua enjoyment (kesenangan) merupakan perasaan nyaman saat melakukan aktivitas, ketiga intrinsic motivation (motivasi intrinsik) merupakan dorongan internal individu untuk mampu menyelesaikan tugasnya secara maksimal. Adapun faktor-faktor flow akademik yaiyu, pertama faktor individu (person factor) merupakan kemampuan yang ada dalam diri individu tesebut, kedua faktor lingkungan (environtmental factor) merupakan tantangan dan dukungan dari luar untuk individu dapat menyelesaikan tugasnya. Flow bermanfaat untuk kegiatan proses pembelajaran siswa (Shernoff et al., 2014). Flow sangat dibutuhkan dalam proses kegiatan belajar untuk siswa dapat menjalani kegiatan belajar dengan perasaan dan perasaan positif (Faria, 2016).

Siswa yang mampu merasakan flow akademik yang baik berarti individu tersebut memiliki pengendalian diri (self regulated learning) dalam proses belajar yang baik. Seseorang yang mampu mengerjakan tugasnya dengan baik dalam kegiatan belajar maka seseorang tersebut memiliki kemampuan meregulasi diri dengan baik (Suciani \& Rozali, 2014). Siswa perlu memiliki self regulated learning yang baik, dan menyebutkan bahwa siswa yang berprestasi merupakan contoh siswa yang mampu meregulasi dirinya sendiri dengan baik (Santrock, 2003).

Self regulated learning suatu proses aktif konstruktif untuk memonitor, mengatur, mengontrol kognisi, dan tingkah laku dalam kegiatan belajar (Wolters, Pintrich, \& Karabenick, 2003). Self regulated learning sebagai kemampuan individu untuk berpartisipasi aktif dalam proses belajar secara metakognitif, motivasional, dan behavioral (Zimmerman, 2002). Seseorang akan mampu untuk mengerjakan tugas-tugasnya dengan baik apabila dalam proses belajarnya memiliki kemampuan meregulasi diri yang baik (Suciani \& Rozali, 2014). Self regulated learning merupakan kondisi individu untuk dapat mengembangkan pemahaman mengenai respon yang sesuai dan tidak sesuai (Ormrod, 2008).

Tiga aspek umum yang membentuk self regulated learning yakni, pertama kognisi merupakan kemampuan seseorang untuk mengatur, mengorganisasi, memonitor, melakukan evaluasi dalam kegiatan belajar, kedua motivasi merupakan pendorong individu dalam kegiatan belajar, ketiga perilaku merupakan cara individu untuk mengatur diri, menyeleksi, dan menciptakan lingkungan yang mendukung aktivitas belajar (Wolters et al., 2003).

Harga diri berperan penting dalam kehidupan individu dan kinerja individu dalam aktivitas yang dilakukan (Walgito, 1989). Self-esteem adalah sebuah evaluasi individu terhadap apa yang dirasakan pada dirnya, untuk menilai seberapa kompenten individu tersebut dapat menilai dirinya 
(DeVito, 2005). Self-esteem merupakan evaluasi yang dibuat individu dan kemampuan individu memandang dirinya, itu mengungkapkan indikaksi besarnya kepercayaan diri individu bahwa dirinya mampu, sukses, berharga, dan berarti (Coopersmith, 1967). Self-esteem merupakan penilaian diri yang dipengaruhi interaksi, penerimaan, penghargaan dari oranglain terhadap individu (Chaplin, 2001).

Salah satu aspek kepribadian yang mempengaruhi flow ialah self-esteem. Adapun empat aspek dalam self-esteem yakni, pertama significance merupakan penerimaan diri dan penghargaan yang diberikan oleh orang lain terhadap individu, kedua competence merupakan usaha individu untuk dapat berhasil dan sukses dalam pencapaian, ketiga power merupakan kemampuan yang dimiliki individu untuk dapat mengontrol perilaku, keempat virtue merupakan ketaatan individu dengan moral, etika, aturan yang berlaku di lingkungan masyarakat (Csikszentmihalyi, Latter, \& Duranso, 2017).

Dukungan sosial memiliki korelasi yang kuat untuk memunculkan flow (Mäkikangas, Bakker, Aunola, \& Demerouti, 2010). Penilitian Yuwanto et al. (2011) menyebutkan bahwa flow akademik dengan dukungan sosial (teman 34,4\%, orang tua 28,7\%, dan pacar 19,1\%) mempengaruhi seseorang dalam meningkatkan flow. Dukungan sosial merupakan ketika individu meminta bantuan pada seseorang atau lingkungannya untuk dapat mengatasi masalah yang sedang dialami (Cohen \& Syme, 1985). Menurut Sarafino (2002) mendefinisikan dukungan sosial sebagai kenyamanan, perhatian, penghargaan, dan bantuan dari orang lain terhadap individu. Ada empat aspek dalam dukungan sosial yakni, pertama emotional support merupakan dukungan dalam bentuk rasa empati, peduli, dan perhatian kepada individu, kedua dukungan penghargaan merupakan ketika individu mendapat dorongan dan penghargaan yang positif dari orang lain, ketiga instrumental support berupa saran yang positif sehingga individu dapat menyelasaikan masalahnya, keempat information support berupa nasihat, petunjuk, dan saran. Selain itu ada faktor-faktor dukungan sosial yakni penerimaan dukungan sosial, jaringan sosial support, dan penyedia dukungan.

Berdasarkan penjelasan di atas menujukkan bahwa kegiatan belajar yang panjang menyebabkan siswa dapat merasakan kelelahan mental dan kelelahan fisik sehingga menyebabkan siswa tidak dapat mengikuti proses pembelajaran dengan nyaman, fokus, dan perasaan yang positif, sehingga penelitian tentang faktor determinan terhadap flow akademik menjadi sangat penting untuk dilakukan. Penelitian ini menguji self-regulated learning, self-esteem, dan dukungan sosial sebagai variabel predictor yang dapat mempengaruhi flow akademik.

\section{Metode Penelitian}

Penelitian ini menggunakan pendekatan kuantitatif dengan desain hubungan kausalitas, yaitu untuk mengetahui ada atau tidaknya hubungan antara dua variabel atau beberapa variabel. Metode survey digunakan untuk mengumpulkan data dengan menyebarkan intrumen kepada partisipan.

\section{Partisipan}

Penelitian ini dilakukan di salah satu Madrasah Aliyah Negeri (MAN) yang menyelenggarakan Program Sistem Kredit Semester (SKS) di Jawa Timur. Sekolah tersebut secara purposive digunakan sebagai lokasi penelitian karena dalam studi preliminary research ditemukan tuntutan akademik atau kurikulum pendidikan yang mengharuskan siswa untuk dapat tetap merasakan flow akademik dalam proses belajar untuk memperoleh hasil yang optimal. Untuk menyeleksi para partisipan digunakan teknik kuota sampling, hasilnya menunjukkan 85 siswa sebagai sampel penelitian Tabel 1 menunjukkan distirbusi partisipan.

Tabel 1. Distribusi Responden

\begin{tabular}{ccc}
\hline Demografi & Jumlah & Persentase \\
\hline Laki-laki & 40 & $47 \%$ \\
Perempuan & 45 & $53 \%$ \\
Jumlah & 85 & $100 \%$ \\
\hline
\end{tabular}

Sumber: Data Pribadi, 2020

\section{Instrumen}

Alat ukur psikologi yang digunakan dalam penelitian ini adalah 4 skala psikoligis yaitu sebagai berikut: (1) Skala Flow Akademik, skala ini mengukur tiga aspek flow akademik yaitu absorption (penyerapan), enjoyment (kesenangan), dan intrinsics motivation (motavasi intrinsik) (Shernoff et al., 
2014). Skala ini terdiri dari 20 aitem dengan reabilitas $(\alpha=.691)$. Contoh penyataan skala psikologi ini antara lain sebagai berikut: bagi saya belajar dan mengerjakan tugas merupakan aktivitas yang menyenangkan $(\mathrm{r}=.598)$, saya susah mengikuti pelajaran saat kegiatan belajar dalam kondisi ramai $(\mathrm{r}=$ .515); (2) Skala Self regulated learning, skala ini mengukur tiga aspek self regulated learning yaitu kognisi, motivasi, dan perilaku (Wolters et al., 2003). Skala ini terdiri dari 20 aitem dengan reabilitas (a $=.782$ ). Contoh pernyataan skala psikologi ini antara lain sebagai berikut: saya tidak mempunyai cara belajar yang sesuai untuk mendapat nilai yang sesuai harapan $(r=.429)$, saya berusaha dengan maksimal saat mengerjakan tugas $(\mathrm{r}=.636)$; (3) Skala Self-esteem, skala ini mengukur empat aspek self esteem yaitu significance, competence, power, dan virtue (Coopersmith, 1967). Skala ini terdiri dari 26 aitem dengan reabilitas $(\alpha=.912)$. Contoh pernyataan skala psikologi ini antara lain sebagai berikut: saya merasa teman-teman di keliling saya dapat menerima saya dengan apa adanya $(r=.532)$, orangtua saya selalu menuyuruh saya belajar untuk memperoleh nilai yang bagus $(r=.414)$; (4) Skala Dukungan Sosial, skala ini mengukur empat aspek dukungan sosial yaitu emotional suport, dukungan penghargaan, instrumental suport, dan information suport (Sarafino, 2002). Skala ini terdiri dari 20 aitem dengan reabilitas $(\alpha=.800)$. Contoh skala pernyataan psikologi ini antara lain sebagai berikut: saya dihargai dan dipercaya dalam menyelesaikan tugas-tugas sekolah $(\mathrm{r}=.570)$, teman-teman selalu membantu saya apabila mengalami kesulitan mengerjakan tugas $(r=.483)$.

\section{Analisis Data}

Analisis regresi berganda digunakan untuk menganaslisis data penelitian. Regresi ganda digunakan untuk memprediksi variabel dependent dengan menggunakan dua atau lebih variabel independent (Muhid, 2019). Disamping itu digunakan teknik stepwise untuk menganalisis pengaruh setiap variabel predictor terhadap variabel flow akademik. Seluruh analisis data menggunakan Program SPSS for windows Versi 23.0.

\section{Hasil Penelitian}

Analisis deskriptif data dalam penelitian mencakup skor empirik dan skor hipotetik. Skala flow akademik yang disusun oleh peneliti terdiri dari 20 aitem dengan lima pilihan jawaban dengan rentang maksimum dan minimum adalah 20x1 sampai dengan 20x5, yaitu 20 sampai 100 dengan mean hipotetiknya $(20+100): 2=60$. Standar deviasi hipotetik dalam penelitian ini adalah $(100-20): 6=13.3$. Perbandingan data empirik dan hipotetik variabel flow akademik dapat dilihat pada tabel di bawah ini:

Tabel 2. Perbandingan Data Empiris dan Hipotesis Flow Akademik

\begin{tabular}{|c|c|c|c|c|c|c|c|c|}
\hline Variabel & \multicolumn{3}{|c|}{ Empirik } & \multirow[t]{2}{*}{ SD } & \multicolumn{3}{|c|}{ Hipotetik } & \multirow[t]{2}{*}{$\mathrm{SD}$} \\
\hline Flow & Min & Max & Mean & & Min & Max & Mean & \\
\hline Akademik & 74 & 93 & 83.32 & 4.632 & 20 & 100 & 60 & 13.3 \\
\hline
\end{tabular}

Sumber: Data Pribadi, 2020

Mengacu pada perbandingan data deskriptif pada table 2, diperoleh bahwa nilai empirik lebih besar dari mean hipotetik yaitu $83.32>60$, maka dapat disimpulkan bahwa flow akademik pada subjek penelitian lebih tinggi daripada populasi pada umumnya.

Subjek kemudian digolongkan ke dalam tiga kategorisasi flow akademik yaitu, flow akademik rendah, sedang, dan tinggi. Berdasarkan table 3 kategorisasi berikut, dapat sisimpulkan bahwa subjek penelitian secara keseluruhan mengalami flow akademik yang sedang.

Tabel 3. Kategorisasi Data Flow Akademik

\begin{tabular}{ccccc}
\hline Variabel & Rentang Nilai & Kategori & Jumlah $(\mathrm{n})$ & Persentase \\
\hline \multirow{3}{*}{ Flow Akademik } & $\mathrm{x}<79$ & Rendah & 13 & $15.3 \%$ \\
& $79 \leq \mathrm{x}<88$ & Sedang & 60 & $70.6 \%$ \\
& $\mathrm{X} \geq 89$ & Tinggi & 12 & $14.1 \%$ \\
& Jumlah & & 85 & $100 \%$ \\
\hline
\end{tabular}

Sumber: Data Pribadi, 2020

Adapun skala self regulated learning yang dipakai dalam penelitian ini terdiri dari 20 aitem dengan kriteria penilaian bergerak dari 1 sampai 5 . Rentang maksimum dan minimumnya adalah 20x1 sampai 20x5, yaitu 20 sampai 100 dengan mean hipotetiknya $(20+100): 2=60$. Standar deviasi hipotetik 
dalam penelitian ini adalah (100-20): $6=13.3$. Perbandingan data empirik dan hipotetik variabel self regulated learning dapat dilihat pada tabel 4 dibawah ini.

Tabel 4. Perbandingan Data Empiris dan Hipotesis Self Regulated Learning

\begin{tabular}{|c|c|c|c|c|c|c|c|c|}
\hline Variabel & \multicolumn{3}{|c|}{ Empirik } & \multirow[t]{2}{*}{ SD } & \multicolumn{3}{|c|}{ Hipotetik } & \multirow[t]{2}{*}{$\mathrm{SD}$} \\
\hline Self & Min & Max & Mean & & Min & Max & Mean & \\
\hline $\begin{array}{c}\text { regulated } \\
\text { learning }\end{array}$ & 72 & 96 & 83.46 & 6.156 & 20 & 100 & 60 & 13.3 \\
\hline
\end{tabular}

Sumber: Data Pribadi, 2020

Mengacu pada perbandingan data deskriptif pada tabel 4, diperoleh bahwa nilai mean empirik lebih besar dari mean hipotetik yaitu 83.46>60, maka dapat disimpulkan bahwa penilaian siswa terhadap self regulated learning pad a subjek penelitian ini lebih tinggi/positif dibandingkan dengan populasi pada umumnya.

Kemudian subjek digolongkan ke dalam tiga kategorisasi penilaian siswa terhadap self regulated learning yaitu penilaian tentang self regulated learning yang negatif, sedang, dan positif. Berdasarkan tabel 5 kategorisasi berikut, dapat disimpulkan bahwa subjek penelitian secara keseluruhan memiliki penilaian yang sedang.

Tabel 5. Kategorisasi Data Penilaian terhadap Self Regulated Learning

\begin{tabular}{ccccc}
\hline Variabel & Rentang Nilai & Kategori & Jumlah $(\mathrm{n})$ & Persentase \\
\hline & $\mathrm{x}<77$ & Rendah & 15 & $17.6 \%$ \\
Self regulated & $77 \leq \mathrm{x}<89$ & Sedang & 55 & $64.7 \%$ \\
learning & $\mathrm{x} \geq 90$ & Tinggi & 15 & $17.6 \%$ \\
& Jumlah & & 85 & $100 \%$ \\
\hline
\end{tabular}

Sumber: Data Pribadi, 2020

Adapun skala self-esteem self-esteem yang dipakai dalam penelitian ini terdiri dari 26 aitem dengan kriteria penilaian bergerak dari 1 sampai 5. Rentang maksimum dan minimumnya adalah 26x1 sampai $26 x 5$, yaitu 26 sampai 130 dengan mean hipotetiknya $(26+130): 2=78$. Standar deviasi hipotetik dalam penelitian ini adalah (130-26): $6=17.33$. Perbandingan data empirik dan hipotetik variabel self ${ }^{-}$ esteem dapat terlihat pada tabel 6 dibawah ini.

Tabel 6. Perbandingan Data Empiris dan Hipotesis Self-esteem

\begin{tabular}{|c|c|c|c|c|c|c|c|c|}
\hline Variabel & \multicolumn{3}{|c|}{ Empirik } & \multirow[t]{2}{*}{ SD } & \multicolumn{3}{|c|}{ Hipotetik } & \multirow[t]{2}{*}{$\mathrm{SD}$} \\
\hline Self - & Min & Max & Mean & & Min & Max & Mean & \\
\hline esteem & 84 & 129 & 103.87 & 10.408 & 26 & 130 & 78 & 17.3 \\
\hline
\end{tabular}

Sumber: Data Pribadi, 2020

Mengacu pada perbandingan data deskriptif pada tabel 6, diperoleh bahwa nilai mean empiric lebih besar dari mean hipotetik yaitu $103.87>78$, maka dapat disimpulkan bahwa penilaian siswa terhadap self-esteem pada subjek penelitian ini lebih tinggi/positif dibandingkan dengan populasi pada umumnya.

Kemudian subjek digolongkan ke dalam tiga kategorisasi penilaian siswa terhadap self-esteem yaitu penilaian tentang self-esteem yang negatif, sedang, dan positif. Berdasarkan tabel 7 kategorisasi berikut, dapat disimpulkan bahwa subjek penelitian secara keseluruhan memiliki penilaian yang sedang.

Tabel 7. Kategorisasi Data Penilaian terhadap Self-esteem

\begin{tabular}{rcccc}
\hline Variabel & Rentang Nilai & Kategori & Jumlah $(\mathrm{n})$ & Persentase \\
\hline \multirow{3}{*}{ Self-esteem } & $\mathrm{x}<93$ & Rendah & 11 & $12.9 \%$ \\
& $93 \leq \mathrm{x}<113$ & Sedang & 56 & $65.9 \%$ \\
& $\mathrm{x} \geq 114$ & Tinggi & 18 & $21.2 \%$ \\
& Jumlah & & 85 & $100 \%$ \\
\hline
\end{tabular}

Sumber: Data Pribadi, 2020 
Adapun skala dukungan sosial yang dipakai dalam penelitian ini terdiri dari 20 aitem dengan kriteria penilaian bergerak dari 1 sampai 5 . Rentang maksimum dan minimumnya adalah 20x1 sampai 20x5, yaitu 20 sampai 100 dengan mean hipotetiknya $(20+100): 2=60$. Standar deviasi hipotetik dalam penelitian ini adalah (100-20) $: 6=13.3$. Perbandingan data empirik dan hipotetik variabel dukungan sosial dapat dilihat pada tabel 8 dibawah ini.

Tabel 8. Perbandingan Data Empiris dan Hipotesis Dukungan Sosial

\begin{tabular}{|c|c|c|c|c|c|c|c|c|}
\hline Variabel & \multicolumn{3}{|c|}{ Empirik } & SD & \multicolumn{3}{|c|}{ Hipotetik } & \multirow[t]{2}{*}{ SD } \\
\hline Dukungan & Min & $\operatorname{Max}$ & Mean & & Min & Max & Mean & \\
\hline Sosial & 70 & 100 & 82.82 & 6.026 & 20 & 100 & 60 & 13.3 \\
\hline
\end{tabular}

Sumber: Data Pribadi, 2020

Mengacu pada perbandingan data deskriptif pada tabel 8, diperoleh bahwa nilai mean empiric lebih besar dari mean hipotetik yaitu $82.82>60$, maka dapat disimpulkan bahwa penilaian siswa terhadap dukungan sosial pada subjek penelitian ini lebih tinggi/positif dibandingkan dengan populasi pada umumnya.

Kemudian subjek digolongkan ke dalam tiga kategorisasi penilaian siswa terhadap dukungan sosial yaitu penilaian tentang dukungan sosial yang negatif, sedang, dan positif. Berdasarkan tabel 9 kategorisasi berikut, dapat disimpulkan bahwa subjek penelitian secara keseluruhan memiliki penilaian yang sedang.

Tabel 9. Kategorisasi Data Penialaian terhadap Dukungan Sosial

\begin{tabular}{ccccc}
\hline Variabel & Rentang Nilai & Kategori & Jumlah (n) & Persentase \\
\hline \multirow{3}{*}{ Dukungan Sosial } & $\mathrm{x}<77$ & Rendah & 15 & $17.6 \%$ \\
& $77 \leq \mathrm{x}<88$ & Sedang & 60 & $70.6 \%$ \\
& $\mathrm{X} \geq 89$ & Tinggi & 10 & $11.8 \%$ \\
& Jumlah & & 85 & $100 \%$ \\
\hline
\end{tabular}

Sumber: Data Pribadi, 2020

Sebelum dilakukan uji hipotesis dengan menggunakan analisis regresi linear berganda, maka terlebih dahulu dilakukan uji asumsi yaitu uji normalitas data, uji linearitas hubungan, uji multikolinearitas, dan uji heteroskidasitas. Uji normalitas data yang digunakan dalam penelitian ini bertujuan untuk mengetahui apakah populasi data tersdistribusi secara normal atau tidak, menggunakan teknik analisis Kolmogrov-Smirnov dengan bantuan SPSS for windows versi 23.0. Data terdistribusi jika nilai signifikansi lebih besar dari .05. Hasil uji normalitas data dapat dilihat pada tabel 10.

Tabel 10. Hasil Uji Normalitas Data

\begin{tabular}{cl}
\hline Variabel & Sig. \\
\hline Self regulated learning & .404 \\
Self-esteem & .435 \\
Dukungan Sosial & .152 \\
Flow Akademik & .119 \\
\hline
\end{tabular}

Sumber: Data Pribadi, 2020

Berdasarkan tabel diatas dapat dilihat hasil uji normalitas data dengan menggunakan analisis One Sample Kolmogrov-Smirnov Test, diperoleh nilai signifikansi pada variabel self regulated learning sebesar $=.404(\mathrm{p}>.05)$; variabel self-esteem sebesar $=.435(\mathrm{p}>.05)$; variabel dukungan sosial sebesar $=.152$ $(\mathrm{p}>.05)$; variabel flow akademik sebesar $=.119$ ( $>$ >.05). Artinya keempat data dalam penelitian ini yaitu data self regulated learning, self-esteem, dukungan sosial, dan flow akademik semuanya berdistribusi normal.

Tabel 11. Uji Linearitas Hubungan

\begin{tabular}{cccc}
\hline Variabel & F & Sig. & Keterangan \\
\hline Self regulated learning - Flow Akademik & 66.113 & 0.000 & Linear \\
Self-esteem - Flow Akademik & 10.101 & 0.003 & Linear \\
Dukungan Sosial - Flow Akademik & 89.088 & 0.000 & Linear \\
\hline
\end{tabular}

Sumber: Data Pribadi, 2020 
Tabel 11 menunjukkan bahwa ketiga variabel predictor yaitu self regulated learning, self-esteem, dan dukungan sosial memiliki hubungan yang linier dengan variabel kriterium yaitu flow akademik. Hal ini diketahui dari nilai signifikansi yang diperoleh, untuk self regulated learning dengan flow akademik sebesar $.000(<.05)$, self-esteem dengan flow akademik sebesar .0003(<.05), dan dukungan sosial sebesar $.000(<.0 .05)$. Dengan demikian dapat disimpulkan bahwa antara self regulated learning dengan flow akademik dinyatakan linear, self-esteem dengan flow akademik dinyatakan linear, dan dukungan sosial dengan flow akademik dinyatakan linear.

Tabel 12 menunjukkan ketiga variabel predictor yaitu self regulated learning, self-esteem, dan dukungan sosial tidak terjadi multikolinearitas. Hal ini diketahui dari nilai Tolerance dan Variance Inflation Factor (VIF) ketiga variabel tersebut.

Tabel 12. Uji Multikolinearitas

\begin{tabular}{cccc}
\hline Variabel & \multicolumn{2}{c}{ Collinearity Statistics } \\
& Tolerance & VIF & Keterangan \\
\hline Self regulated learning & 0.373 & 2.681 & \\
Self esteem & 0.578 & 1.731 & Tidak Terjadi \\
Dukungan Sosial & 0.435 & 2.301 & Multikolinearitas \\
\hline
\end{tabular}

Sumber: Data Pribadi, 2020

Pada gambar 1 menunjukkan hasil uji heteroskidasitas, di mana pada grafik Scatterplot terlihat bahwa tidak ada pola yang jelas serta titik-titik tersebut menyebar di atas dan di bawah angak o pada sumbu Y. Hal ini menunjukkan bahwa data dalam penelitian ini tidak terjadi heteroskidasitas.

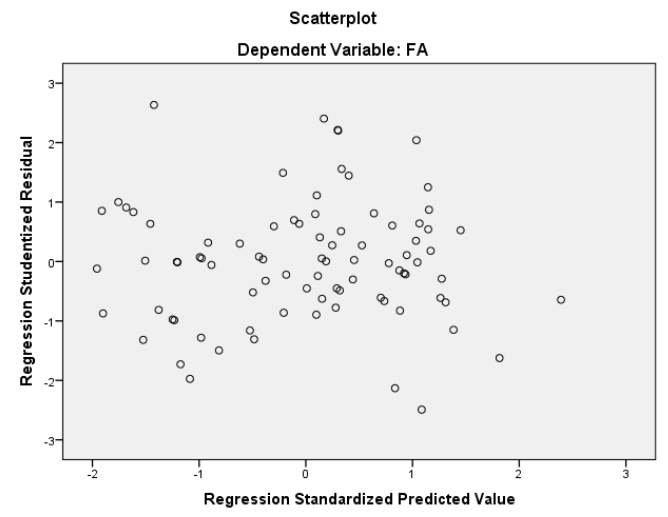

Gambar 1. Grafik Scatterplot

Sumber: Data Pribadi, 2020

Berdasarkan hasil uji asumsi diatas menunjukkan bahwa keempat data dalam penelitian ini semuanya berdistribusi normal, hubungan antar ketiga variabel predikyor dengan variabel kriterium juga berhubungan secara linear, ketiga variabel prediktor terhindar dari multikolinearitas, dan datadata dalam penelitian ini tidak terjadi heteroskidasitas. Sehingga, penelitian ini dapat digunakan pengujian statistic parametric yaitu analisis regresi berganda untuk menguji ketiga variabel prediktor dengan variabel kriterium.

Hasil analisis statistik pada tabel 13 menunjukkan bahwa secara simultan ada pengaruh positif yang signifikan ketiga variabel predictor yaitu self regulated learning, self-esteem, dan dukungan sosial terhadap flow akademik $(\mathrm{F}=38.874 ; \mathrm{P}=.000)$. Penelitian ini membuktikan bahwa self regulated learning, self-esteem, dan dukungan sosial merupakan prediktor yang signifikan terhadap flow akademik. Pengaruh ketiga variabel prediktor sebesar 59\% terhadap flow akademik, 41\% dipengaruhi oleh variabel yang lain. 
Tabel 13. Analisis Regresi Berganda Variabel Prediktor terhadap Flow Akademik

\begin{tabular}{cc}
\hline Statistic & Value \\
\hline $\mathrm{F}$ & 38.874 \\
$\mathrm{P}$ & .000 \\
$R$ & .768 \\
$R$ Square & .590 \\
\hline
\end{tabular}

Sumber: Data Pribadi, 2020

Tabel 14 menunjukkan hasil uji parsial, di mana ada pengaruh yang signifikan antara self regulated learning terhadap flow akademik $(B=.450 ; \mathrm{t}=3.856 ; \mathrm{p}=.000)$, self-esteem terhadap flow akademik $(B=-.273 ; \mathrm{t}=-2.914 ; \mathrm{p}=.005)$, dukungan sosial terhadap flow akademik $(B=.526 ; \mathrm{t}=4.876 ; \mathrm{p}=.000)$, artinya semakin positif penilaian siswa terhadap self regulated learning, self-esteem, dan dukungan sosial maka semakin tinggi juga flow akademik yang dirasakan siswa, sebaliknya apabila penilaian siswa terhadap self regulated learning, self-esteem, dan dukungan sosial rendah maka semakin rendah juga flow akademik yang dirasakan oleh siswa.

Tabel 14. Pengaruh Variabel Prediktor terhadap Flow Akademik

\begin{tabular}{cccc}
\hline Predictors Variables & $\mathrm{B}$ & $\mathrm{T}$ & $\mathrm{P}$ \\
\hline Self regulated learning & .450 & 3.856 & .000 \\
Self-esteem & -.273 & -2.914 & .005 \\
Dukungan Sosial & .526 & 4.876 & .000 \\
\hline
\end{tabular}

Sumber: Data Pribadi, 2020

Hasil penelitian pada 85 siswa di Madrasah Aliyah Negeri (MAN) yang menyelenggarakan Program Sistem Kredit Semester (SKS) ini menguatkan kembali temuan preliminary research. Hal ini dibuktikan dalam penelitian ini, yaitu berdasarkan data deskriptif diperoleh bahwa nilai mean empiric lebih besar dari mean hipotetik yaitu $83.32>60$, di mana sebanyak 70.6\% rata-rata siswa mengalami flow akademik yang tergolong sedang. Sedangkan data sekriptif tentang self regulated learning, ratarata penilaian siswa terhadap self regulated learning lebih tinggi (perbandingan mean empiric dengan mean hipotetik $=83.46>60$ ), namun data menunjukkan bahwa terdapat $64.7 \%$ penilaian siswa terhadap self regulated learning tergolong sedang. Data deskriptif tentang self-esteem, rata-rata penilaian siswa terhadap self-esteem lebih tinggi (perbandingan mean empiric dengan mean hipotetik= $103.87>78$ ), namun data menunjukkan bahwa terdapat $65.9 \%$ penilaian siswa terhadap self-esteem tergolong sedang. Begitu juga data deskriptif tentang dukungan sosial, rata-rata penilaian siswa terhadap dukungan sosial lebih tinggi (perbandingan mean empiric dengan mean hipotetik= $83.46>60$ ), namun data menunjukkan bahwa terdapat $70.6 \%$ penilaian siswa terhadap dukungan sosial tergolong sedang.

\section{Pembahasan}

Hasil pengujian statistik menunjukkan bahwa penelitian ini membuktikan bahwa self regulated learning, self-esteem, dan dukungan sosial merupakan prediktor yang signifikan terhadap flow akademik. Penelitian ini juga menunjukkan bahwa secara simultan ada hubungan positif yang signifikan terhadap flow akademik. Secara parsial, hasil penelitian menunjukan bahwa ada hubungan positif yang signifikan self-regulated learning, self-esteem, dukunagn sosial terhadap flow akademik. Artinya, semakin positif penilaian siswa terhadap self regulated learning, self-esteem, dukungan sosial maka semakin tinggi juga flow akademik yang dirasakan siswa. Sebaliknya, semakin rendah self regulated learning, self-esteem, dukungan sosial seorang siswa maka semakin rendah juga flow akademik yang dirasakan siswa.

Temuan penelitian ini mendukung temuan penelitian-penelitian sebelumnya yang menyebutkan dalam penelitiannya terdapat hubungan yang signifikan antara self regulated learning dengan flow akademik. Siswa yang mampu merasakan flow akademik yang baik berarti individu tersebut memiliki pengendalian diri (self regulated learning) dalam proses belajar yang baik (Wati \& Firman, 2018). Seseorang yang mampu mengerjakan tugasnya dengan baik dalam kegiatan belajar maka seseorang tersebut memiliki kemampuan meregulasi diri dengan baik (Suciani \& Rozali, 2014). Self regulated learning suatu proses aktif konstruktif untuk memonitor, mengatur, mengontrol kognisi, dan tingkah laku dalam kegiatan belajar (Wolters et al., 2003). Siswa perlu memiliki self regulated learning yang 
baik, dan menyebutkan bahwa siswa yang berprestasi merupakan contoh siswa yang mampu meregulasi dirinya sendiri dengan baik (Santrock, 2003).

Penelitian terdahulu menyebutkan bahwa terdapat hubungan antara self-esteem dengan flow akademik pada siswa (Djau \& Cahyono, n.d.). Dijelaskan juga pada penelitian lain yaitu hasil penelitian yang menunjukkan ada hubungan positif antara self-esteem dengan flow (Hanivah, 2016). Harga diri berperan penting dalam kehidupan individu dan kinerja individu dalam aktivitas yang dilakukan (Walgito, 1989). Self-esteem merupakan evaluasi yang dibuat individu dan kemampuan individu memandang dirinya, itu mengungkapkan indikaksi besarnya kepercayaan diri individu bahwa dirinya mampu, sukses, berharga, dan berarti (Coopersmith, 1967).

Penelitian sebelumnya menjelaskan bahwa ada hubungan positif antara dukungan sosial dengan flow akademik (Chandra, 2013). Selanjutnya pada penelitian (Yuwanto et al. 2011) Yuwanto juga menunjukkan dukungan sosial dapat memengaruhi seseorang untuk dapat meningkatkan flow. Dukungan sosial merupakan ketika individu meminta bantuan pada seseorang atau lingkungannya untuk dapat mengatasi masalah yang sedang dialami (Cohen \& Syme, 1985). Dukungan sosial sebagai kenyamanan, perhatian, penghargaan, dan bantuan dari orang lain terhadap individu. Siswa yang mampu meregulasi diri (self regulated learning), juga memiliki percaya diri dan dapat mengenali dirinya secara baik (self-esteem), ditambah dengan dukungan sosial yang positif dari lingkungannya cenderung akan berdampak positif pada flow akademik yang diraskan di lingkungan sekolah agar memperoleh hasil belajar yang optimal (Sarafino \& Smith, 2013).

\section{Kesimpulan}

Berdasarkan penjelasan tersebut maka dpat disimpulkan bahwa secara simultan ada pengaruh positif yang signifikan antara self regulated learning, self-esteem, dan dukungan sosial terhadap flow akademik. Artinya, variabel self regulated learning, self-esteem, dukungan sosial merupakan variabel predictor yang memperkuat terbentuknya flow akademik pada siswa. Secara parsial, hasil penelitian ini menunjukkan bahwa self regulated learning, self-esteem, dan dukungan sosial yang tinggi terhadap flow akademik maka semakin tinggi pula flow akademik yang dirasakan siswa, sebaliknya jika self regulated learning, self-esteem, dan dukungan sosial rendah maka semakin rendah juga flow akademik yang dirasakan siswa.

Temuan penelitian ini berimplikasi pada pentingnya rasa flow akademik pada siswa agar dapat mengikuti pross pembelajaran dengan secara maksimal dan merasakan pengalaman yang menyenangkan dalam belajar. Oleh karena itu, disarankan pada para guru dan orang-orang yang berada di lingkungan sekolah dapat mendukung dan meningkatkan terciptanya flow akademik yang dapat dirasakan siswa secara baik dalam proses belajar, agar siswa tidak cepat merasa jenuh dan bosan ketika mengikuti pelajaran di kelas maupun di luar kelas.

\section{DAFTAR PUSTAKA}

Al-Qawiy. (2004). Mengatasi Kejenuhan. Jakarta: Khalifa.

Chandra, R. I. (2013). GO WITH THE FLOW: DUKUNGAN SOSIAL DAN FLOW AKADEMIK PADA MAHASISWA. Calyptra: Jurnal Ilmiah Mahasiswa Universitas Surabaya, 2(1). Retrieved from https://journal.ubaya.ac.id/index.php/jimus/article/view/148

Chaplin, J. P. (2001). Kamus Lengkap Psikologi. Jakarta: Grafindo.

Cohen, S., \& Syme, S. L. (1985). Issues in the Study and Application of Social Support. In S. Cohen \& S. L. Syme (Eds), Social Support and Health. San Diego, CA: Academic Press.

Coopersmith, S. (1967). The Antecedents of Self-esteem. San Francisco: W. H. Freeman.

Csikszentmihalyi, M., Latter, P., \& Duranso, C. W. (2017). Running Flow. Canada: Human Kinetics Publishers.

Daryanto. (2005). Evaluasi Pendidikan. Jakarta: Rineka Cipta.

DeVito, J. A. (2005). Human Communication: The Basic Course (10th ed.). USA: Allyn \& Bacon.

Djau, N. R. F., \& Cahyono, R. (n.d.). Hubungan antara Self-esteem dengan Flow Akademik pada Siswa Cerdas Istimewa. Jurnal Psikologi Pendidikan Dan Perkembangan, 6(1), 65-71.

Faria, N. (2016). Positive Psychology and Student Success: How Flow, Mindfulness, and Hope Are Related to Happiness, Relationships, and GPA. California State University Stanislaus, California. 
Furlong, M. J., Gilman, R., \& Huebner, S. (2009). Handbook of Positive Psychology in Schools. In Routledge, Taylor \& Francis Group (2nd ed.). New York: Routledge, Taylor \& Francis Group.

Hanivah, L. S. (2016). Hubungan Antara Self Esteem dengan Flow pada Atlet University Surabaya Basketball Association (Skripsi). Universitas Surabaya, Surabaya.

Kartono. (1990). Psikologi Perkembangan Anak. Bandung: CV. Mandar.

Lee, E. (2005). The Relationship of Motivation and Flow Experience to Academic Procrastination in University Students. The Journal of Genetic Psychology, 166(1), 5-15. https://doi.org/10.3200/GNTP.166.1.5-15

Mäkikangas, A., Bakker, A. B., Aunola, K., \& Demerouti, E. (2010). Job resources and flow at work: Modelling the relationship via latent growth curve and mixture model methodology. Journal of $\begin{array}{lllll}\text { Occupational and Organizational Pychology, } & \text { 83(3), }\end{array}$ https://doi.org/10.1348/096317909X476333

Muhid, A. (2019). Analisis Statistik: 5 Langkah Praktis Analisis Statistik dengan SPSS for Windows (2nd ed.). Sidoarjo: Zifatama Jawara.

Ofianto, O. (2015). EVALUASI PROGRAM PERCEPATAN/AKSELERASI BELAJAR DI SD MUHAMMADIYAH SAPEN YOGYAKARTA. Humanus, 14(1), 63-70. https://doi.org/10.24036/jh.v14i1.5403

Ormrod, J. E. (2008). Psikologi Pendidikan: Membantu Siswa Tumbuh dan Berkembang (6th ed.). Retrieved from http://lib.ui.ac.id

Prawitasari, J. E. (2011). Psikologi Terapan: Melintas Batas Disiplin Ilmu. Jakarta: Erlangga.

Purwati, E., \& Akmaliyah, M. (2016). Hubungan antara Self Efficacy dengan Flow Akademik pada Siswa Akselerasi SMPN 1 Sidoarjo. Psympathic: Jurnal Ilmiah Psikologi, 3(2), 249-260. https://doi.org/10.15575/psy.v3i2.1113

Rustaman. (2011). Ketermapilan Bertanya dalam Pembejaran IPA dalam Handout Bahan Pelantikan Guru-guru IPA SLTA Se-kota Bandung di PPG IPA. Jakarta: DepDikNas.

Santrock, J. W. (2003). Adolescence: Perkembangan Remaja (6th ed.). Jakarta: Erlangga.

Sarafino, E. P. (2002). Health Psychology: Biopsychosocial Interactions (Fourth). New jersey: HN Wiley.

Sarafino, E. P., \& Smith, T. W. (2013). Health Psychology: Biopsychosocial Interactions (8th ed.). Retrieved from https://books.google.co.id/books?id=HOGYAgAAQBAJ

Shernoff, D. J., Abdi, B., Anderson, B., \& Csikszentmihalyi, M. (2014). Flow in schools revisited: Cultivating engaged learners and optimal learning environments. In Educational Psychology Handbook Series. Handbook of positive psychology in schools, 2nd ed (pp. 211-226). New York, NY, US: Routledge/Taylor \& Francis Group.

Suciani, D., \& Rozali, Y. A. (2014). Hubungan Dukungan Sosial Dengan Motivasi Belajar Pada Mahasiswa Universitas Esa Unggul. Jurnal Psikologi, 12(2).

Syah, M. (2012). Psikologi Belajar. Jakarta: Raja Grafindo.

Thursan, H. (2000). Belajar secara Efektif. Jakarta: Puspa Swara.

Walgito, B. (1989). Pengantar Psikologi Umum. Yogyakarta: Andi Offset.

Wati, S., \& Firman, F. (2018). Hubungan Self Regulated Learning dengan Flow Akademik Siswa. Jurnal Neo Konseling. https://doi.org/10.24036/xxxxxxxxxxx-x-xx

Wolters, C. A., Pintrich, P. R., \& Karabenick, S. A. (2003). Assessing Academic Self-regulated Learning. Presented at the Indicators of Positive Development: Definitions, Measures, and Prospective Validity, Maryland. Retrieved from https://www.childtrends.org/massachusetts_122016/assessing-academic-self-regulated-learning

Yuwanto, L., Siandhika, L., Budiman, A. F., \& Prasetyo, T. I. (2011). Stres Akademik Dan Flow Pada Mahasiswa (Universitas Pelita Harapan Jakarta). Retrieved from http://www.ubaya.ac.id/2018/content/articles_detail/13/Stres-Akademik-dan-Flow-padaMahasiswa.html

Zimmerman, B. J. (2002). Becoming a Self-Regulated Learner: An Overview. Theory Into Practice, 41(2), 64-70. https://doi.org/10.1207/s15430421tip4102_2 